\title{
Control of skippers' fishing strategies and crew labour by companies: Role of the remuneration system
}

\author{
Christophe Béné \\ Present address: Station Zoologique, BP 28, 06234 Villefranche-sur-Mer cedlex, Fronce. \\ E-mail: cbene@ccrvobss.vlfr.fr
}

Rccived October 31, 1996; accepted February 27, 1997.

Béné C. Aquat. Living Resour., 1997, 10, 127-136.

Abstract

Résumé
In this study, the remuneration system applied in the French Guyana shrimp fishery is analyzed in rclation to the market changes that this fishery has experienced since 1985. The contract used for the crew members is not the classical share contract usually observed in fisheries. It is a piece rate wagc with quality-bonuses. In the classical contract theory literature the piece ratc contract is thought to avoid effort shirking but to induce quality shirking. The bonuses are introduced here in order to limit the quality shirking which may occur during grading and storing operations on board. The skippers' contract also differs from the share contract. It is based on remuneration parameters controlled by the companies. By changing these parameters between 1987 and 1991, the companies led the skippers to modify their fishing strategies and especially to concentrate their efforts towards small sized shrimp. The companies thus became able to respond to the increasing demand for small shrimp categories which characteriscs the French market. The evolution of the spatial distribution of the flect effort over the same period is consistent with this hypothesis: the lleet has moved towards fishing zones where small shrimp are known to be in abundance.

Keywords: Remuncration system, fishing strategies, crew labour monitoring, contract theory, French Guyana shrimp fishery.

Contrôle des stratégies de pêche des capitaines et du travail de l'équipage par les armements: le rôle du système de rémunération.

Dans cette étude, l'auteur analyse le système de rémunération de la pêcherie crevettière guyanaise en relation avec les contraintes commerciales imposées par les marchés. Pour les membres d'équipage, le contrat diffère du contrat dit « à la part » classiquement observé dans le secteur de la pêche. Il s'agit d'un contrat " à la pièce » complété par des bonus. Le contrat à la pièce permet d'inciter au travail, cependant il induit un travail rapide mais sans soin. Le rôle des bonus est de corriger cette tendance en encourageant les efforts sur la qualité de conditionnement à bord des crevettiers. Le contrat des capitaines lui aussi diffère du contrat à la part. Il est basé sur des coefficients de rémunération qui sont contrôlés par les armements. L'analyse móntre que ces paramètres ont été modifiés entre 1987 et 1991 de telle sorte que les capitaines furent ainsi amenés à changer leurs stratégies de pêche et en particulier à concentrer leur effort sur les petites catégories. Les armements furent alors en mesure de répondre à la demande importante en petites crevettes qui caractérise le marché français. L'analysc de la répartition spatiale de l'effort de pêche est en accord avec ces résultats: on observe que la flottille s'est progressivement rapprochée de la côte, là où les crevettes de petites tailles sont abondantes.

Mots-clés : Système de rémunération, stratégies de pêche, contrôle du travail de l'équipage, théorie des contrats, pêcherie crevettière guyanaise. 


\section{INTRODUCTION}

\section{Contract theory in fisheries}

In systems of exploitation of natural resources such as agriculture, the share contract is almost universal throughout the world (Cheung, 1969; Stiglitz, 1974; Reid, 1976). Under this form of contract, the worker's remuneration is based on a share of the revenue received from the harvest sales. The complement of this share comes back to the landlord. In fisheries also, this type of remuneration arrangement has been widely adopted for a long time (Zoeteweij, 1956). Maran (1974) for instance recalls that during the $\mathrm{xI}^{\text {th }}$ century, whaling crews' wages were already based on this system. The reason for this preference was the owners' belief that: "compensation by shares increased crew's productivity: lookouts were sharper, boat crews were quicker, and blubber cutters were faster when paid by shares". Incentive effects are thought to occur because share contracts reduce worker's incentive to shirk. It rewards them with shares in the output they produce, in opposition to the fixed wage contracts under which the remuneration does not depend on the output quantity (Newbery, 1977).

In traditional literature, this 'incentive effect' is generally associated with the 'risk-sharing' property to explain the widespread preference of share contracts to other remuneration schemes in agriculture and fisheries (Stiglitz, 1974; Sutinen, 1979). Indeed, in uncertain environments, the total output, its subsequent revenue and production costs are highly variable. With respect to this uncertainty, the share system allows the workers to share risks with the owner rather than bearing them completely as under fixed rent. In the fisheries, the standard theoretical studies on share contract (Sutinen, 1979; Anderson, 1982; Plourde and Smith, 1989) proposed the formula: $\{r \times p \times Q$ versus $(1-r) p \times Q\}$ to describe the relationship binding the ship owners to the non-owner fishermen where $(r)$ represents the share of the fishermen and $(1-r)$ the complement of this share coming back to the ship owner, $(p)$ is the price and $(Q)$ the output. This form can be considered as the 'traditional' scheme since it is similar to the algebraic form adopted in the agricultural sector by most of the studies (Stiglitz, 1974; Reid, 1976; Bell, 1977; Braverman and Stiglitz, 1982).

As far as the empirical cases-studies in fisheries are concerned, very few studies have been proposed so far. Most of the studies are theoretical (Plourde and Smith, 1989; Haemaelaeinen et al., 1990; Anderson, 1994). One exception is the work of Sass and Roberts (1979) who studied the contract of the fishery of the Gulf of Mexico. They concluded that the form of this system was a share arrangement. In the French Guyana shrimp fishery the remuneration system has also been studied. It was initially identified as a share system (Le Cabellec, 1984; Gilly and Cochet, 1988). However, the present analysis will show that this remuneration contract actually differs from the 'traditional' share contract. This study is actually the analytical complement of a previous article (Béné, 1996) which tried to emphasise the coupled impact of the resource and market dynamics on fishermen's behaviour.

\section{The French Guyana shrimp fishery: history and background}

The French Guyana shrimp fishery is a trawl fishery which has been exploiting the stock of Penaeid shrimp off the coast of the French Guyana (a French over seas territory located at the north-east border of Brazil) since the early 1960s (Villegas and Dragovitch, 1984; Dintheer et al., 1991). The principal species is the "brown" shrimp Penacus subtilis which represents now more than $95 \%$ of the shrimp catch (Moguedet et al., 1994). Like most Penaeid species, P. subtilis is characterised by a depth-dependent distribution of the adult stock: the youngest adult stages are usually found near the coast while larger mature shrimp are caught offshore (Venaille, 1979; Garcia et al., 1985; Lhomme, 1992). This depth-dependent distribution has an important consequence for the fishermen's choice of fishing strategies. By distributing their effort inshore or offshore, the skippers are able to modify to a certain extent the size composition of their catches and thus to increase the proportions of given targeted commercial categories. The second consequence of this depthdependent distribution is that coastal zones always offer higher abundance levels than offshore areas.

During the 1980s, the fishery was made up of three different fleets. An American fleet has been present since the beginning of the exploitation in the early 1960s. Japanese companies first entered the fishery at the end of the 1970s and French companies during the 1980s (Dintheer et al., 1991). In 1981, the French government launched a nationalisation programme the objective of which was the progressive replacement of the foreign companies by French companies. However, the replacement of the American and Japanese fleets entailed an unfortunate and unexpected consequence : the closure of the market opportunities offered so far by the USA and the Japan (Béné and Moguedet, 1994). This market closure was due to the fact that the US and Japanese companies 'pushed out' from the French fishing zone redistributed their boats in the just neighbouring Surinamian and Guyana zones and thereby continued to supply their respective markets without leaving opportunities to the French companies to take over on these markets. Consequently, the French market, and to a lesser extent, the European market became progressively the sole export outlet for the fishery (Fig. 1). This export re-orientation was associated with a change in the size of the shrimp preferentially purchased by the processors. The Japanese processors only purchased very large shrimp whereas French processors require smaller shrimp (Josupeit, 1992; Hottlet, 1992). Thus the implementation of the French government programme 


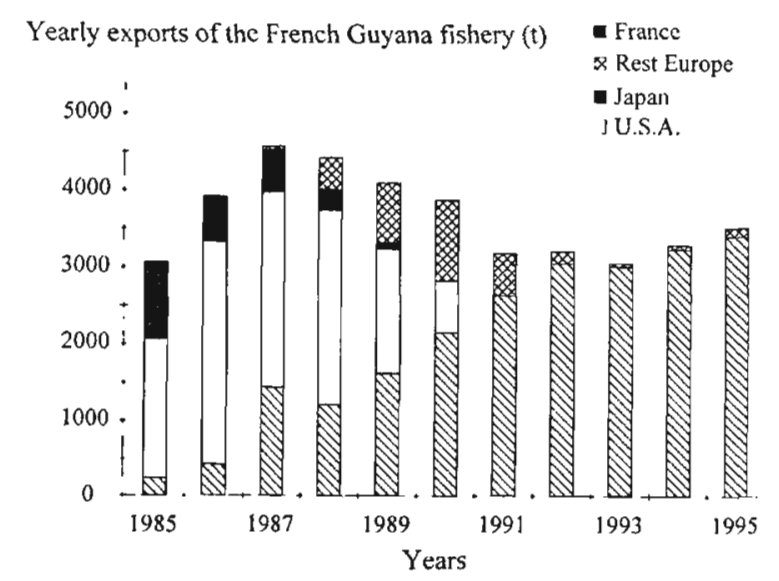

Figure 1. - Exports for the French Guyana fishery over the period 1985-95 (in tonnes). Starting from less than $200 \mathrm{t}$ in 1985 (about $5 \%$ of the total exports), the French market absorbs after 1991 more than 95\% of the total French Guyana fishery exports (source: National Department of Forcign Trade Statistics).

led the French companies to change their commercial strategies. From 1988 onwards, they were required to export smaller shrimp to French and European processors than they used to do with Japanese or US importers. Presently, the French market absorbs about $95 \%$ of the French Guyana fishery's exports.

\section{METHODS}

\section{Algebraical analysis of the contracts}

Since the 1980s, the fleet consists of 70 Floridatype trawlers owned by about ten companies. Each of the ship-owning company contracts captains to conduct the fishing trips. The crew members are then chosen by the captains amongst the community of non-owner fishermen. During each trip, in addition to gear manipulating, the main task for the crew consists of separating the shrimp from the by-catch (which represent more than $90 \%$ of the total catch, Moguedet et al., 1994) and of sorting the shrimp into the different commercial categories in which the shrimp are then supplied and purchased on the market.

The fishermen's income is split up in two different contracts, one proposed to the captains (skippers) and one to the crew members. Each contract is made up of two different components: a first fraction which corresponds to a non-bonus income and a second fraction which embodies the various bonuses. For the captains' contract, let $\left(K_{t}\right)$ be the non-bonus fraction for a given trip $(t)$. The pay slips analysis indicates that $\left(K_{t}\right)$ is of the following form:

$$
K_{t}=\sum_{c=1}^{7}\left(q_{c, t} \times \nu_{c}\right)
$$

where $\left(q_{c, t}\right)$ is the quantity of the commercial category (c) landed for a given trip $(t), c=\{1,2, \ldots, 7\}$ being the seven commercial categories $(1$ is the category of the largest shrimp and 7 the category of the smallest shrimp), and $\left(\nu_{c}\right)$ are the remuneration parameters vector (French Francs per kilogram: FF $\left.\mathrm{kg}^{-1}\right)$. This vector $\left(\nu_{c}\right)$ is set by the companies and reconsidered about every six months. It tends however to be approximately comparable between the different companies. This homogeneity can be seen as the result of the competition within the labour market of the fishery. The avcrage values of the parameters $\left(\nu_{c}\right)$ are displayed for the years 1987,1989 , and 1991 in Table 1.

Table 1. - Yearly averagc values of the skippers' remuneration parameters $\left(\nu_{c}\right)$ (French Francs $\mathrm{kg}^{-1}$ ) for the years 1987, 1989. and 1991 (source: Gilly and Cochet, 1988; C.F.P. (V) Armag(V) Guyapêche $\left.{ }^{(\mathrm{V})}\right)$.

\begin{tabular}{llllllll}
\hline & \multicolumn{7}{c}{ Categories } \\
\cline { 2 - 8 } Year & 1 & 2 & 3 & 4 & 5 & 6 & 7 \\
\hline 1987 & 12.0 & 10.5 & 8.0 & 5.7 & 3.2 & 2.6 & $0.0\left(^{*}\right)$ \\
1989 & 11.9 & 11.5 & 10.5 & 8.0 & 5.7 & 4.0 & 1.0 \\
1991 & 14.2 & 13.2 & 12.3 & 9.5 & 7.3 & 6.1 & 4.0 \\
\hline
\end{tabular}

(V): French company in activity during the period analysed.

${ }^{(*)}$ : The category 7 was not remunerated in 1987 .

In an other respect, the study of the crew members' pay slips shows that, for a given trip $(t)$ the crew's non-bonus fraction $\left(L_{\ell}\right)$ is given by:

$$
L_{t}=\mu Q_{t}
$$

" where $(\mu)$ is the share parameter $\left(\mathrm{FF} \mathrm{kg}^{-1}\right)$ received by the crew members for each kilogram of shrimp landed. The parameter $(\mu)$ is independent of commercial category. For instance, $\mu$ was $0.95 \mathrm{FF} \mathrm{kg}^{-1}$ in 1987 (Gilly and Cochet, 1988). Crew members also receive several trip bonuses based on grading and quality requirements. Let $\left(A_{t}\right)$ represent the percentage of broken plus autolysed shrimp in the landings of trip $(t)$, the general structure of the bonus component $\left(B_{t}\right)$ is:

$$
\begin{gathered}
B_{t}=(\psi+\varphi) Q_{t}+\varepsilon \sum_{c=1}^{2} q_{c, t} \\
\text { with }\left\{\begin{array}{l}
\psi>0 \text { if } Q_{t} \geq \Psi \\
\psi=0 \text { otherwise }
\end{array}\right. \\
\text { and }\left\{\begin{array}{l}
\varphi>0 \text { if } A_{t}<\Phi \\
\varphi=0 \text { otherwise }
\end{array}\right.
\end{gathered}
$$

where $(\psi)$ is the production bonus parameter $\left(\mathrm{FF} \mathrm{kg}^{-1}\right.$ ) received by each crew member provided that the total 
landings of the trip $\left(Q_{I}\right)$ is greater than a given catch threshold $(\Psi)$. The parameter $(\varphi)$ represents a quality and grading bonus ( $\mathrm{FF} \mathrm{kg}^{-1}$ ) received if the percentage $\left(A_{t}\right)$ is lower than a given quality threshold $(\Phi)$. The parameter $(\varepsilon)$ determines the bonus ( $\mathrm{FF} \mathrm{kg}^{-1}$ ) received for the quantity of shrimp of the two largest categories (1 and 2) landed per trip. For illustration, in 1987, the bonus parameter $\left(\psi^{\prime}\right)$ was $0.14 \mathrm{FF} \mathrm{kg}^{-1}$ and the associated threshold $(\psi)$ was $4320 \mathrm{~kg}$ per trip. For the same year, $(\varepsilon)$ was $0.44 \mathrm{FF} \mathrm{kg}$ ', the bonus parameter $(\varphi)$ was $0.30 \mathrm{FF} \mathrm{kg}^{-1}$ and the associated threshold $(\phi)$ was $4 \%$ (Gilly and Cochet, 1988). The parameters, the catch and quality thresholds were all set in advance by the companies.

\section{RESULTS}

Anderson (1982) has pointed out that the cost of producing effort will be higher than necessary in fisheries where (a) skippers have latitude in determining where in the fishing zone the effort will be allocated and when to change areas during a particular trip and (b) when the percentage share of variable cost paid by fishermen is lower than their percentage share of revenucs. In the present case, Anderson's condition (a) is fulfilled: skippers choose the fishing zone and when to change it during their trips. In other respects, since the frequency of contract reconsideration is only about twice a year, it appears from (1) and (2) that neither the skippers nor the crew members support the cost variability with the same magnitude as the companies. Likewise, (1) and (2) indicate that the fishermen do not support the monthly fluctuations in the production cost related to fishing effort. Only companies do. Consequently, the fishermen can increase the exploration effort for fishing zones during low yicld months without bearing the proportional rise in variable cost. This situation is thus likely to lead to an inefficicnt production of fishing effort especially during the months of low catch rates. This does not mean however that the fishermen's variable cost share is zero though it does not appear explicitly in (1) and (2). Neither does it mean that fishermen's cost share is lower than their revenue share (condition (b) in Anderson's analysis). One may expect the companies to estimate the average annual fishing cost and to impose it through the non-bonus parameters $(\mu)$ and $\left(\nu_{c}\right)$.

\section{Proof of the difference with share contract}

When transposing to the present case study, and taking into account the existence of seven different category prices, the "traditional form" of share contract $\{r \times p \times Q$ versus $(1-r) p \times Q\}$ becomes: $r \sum_{c=1}^{7}\left(q_{c, t} \times p_{c}\right)$ versus $(1-r) \sum_{c=1}^{7}\left(q_{c, t} \times p_{c}\right)$. This differs from the arrangement (1) in that in (1) the captain's fraction $\left(K_{t}\right)$ is not the complement of the company's part. It would be so if and only if the parameters $\left(\nu_{c}\right)$ were such that $\nu_{r^{*}}=$ $(1-r) p_{c}, \forall r$. In this case, $\left(K_{t}\right)$ would become: $K_{t}=\sum_{r=1}^{7}\left(g_{r, t}(1-r) p_{c}\right)=(1-r) \sum_{r=1}^{7}\left(q_{c, t} \times \gamma_{r}\right)$ which is the form of the share contract. However, the parameters $\left(\nu_{c}\right)$ are set by the companies and reconsidered only every six months. Consequently, a gap may exist between these values and the market prices. The companies indeed enjoy a certain level of flexibility to set the parameters vector. This possibility for the companies to "decouple" the parameters $\left(\nu_{c}\right)$ from the corresponding market prices $\left(p_{c}\right)$ will be tested (cf. step (A) of the test procedure below).

As far as the crew remuneration contract is concerned, it is clear from (2) that this contract is not a share contract. It is a piece rate contract. Under this form of contract, the income $\left(L_{t}\right)$ is directly related to the output $\left(Q_{i}\right)$ obtaincd during the trip, not to the gross revenue realised $\sum_{r=1}^{7}\left(q_{r, t} \times p_{t}\right)$ as would be the case if the arrangement was of the form $(1-r) \sum_{r=1}^{7}\left(q_{c, t} \times p_{t}\right)$. This means that, for a given output, the crew members receive a constant non-bonus fraction, whatever the landing composition of the trip. Only the catch weight is considered. Accordingly, the crew bears catch volume variations induced by resource fluctuations, but not market price fluctuations.

Finally, note that there would not be any difference between piece rate and share contracts if and only if shrimp were sold under one unique category price $p=p_{c} \forall c$ and $\mu=(1-r) p$. Indeed, in that hypothetical case, the share contract would reduce to:

$$
\begin{aligned}
& (1-r) \sum_{r-1}^{7}\left(q_{r, t} \times p_{t}\right)=(1-r) \sum_{r=1}^{7}\left(q_{c, t} \times p\right) \\
& =(1-r) p \sum_{r-1}^{7} q_{c, t}=(1-r) p \times Q_{t}=\mu \times Q_{t} .
\end{aligned}
$$

\section{DISCUSSION}

The existence of the piece rate contract and its survival for more than 30 years in the French Guyana fishery, whereas the share contract is adopted in almost all other fisheries around the world, may appear somewhat odd. Another way to interpret this situation is to argue that if this particular and relatively complicated system has been maintaincd for so long, this is certainly because it offers advantages for the employers (the companies). 


\section{Effort shirking and quality shirking issues: theoretical analysis}

In this first part of the discussion, we focus on the crew members' remuneration contract and we propose a possible explanation for the fact that it has been preferred to the usual share contract. We know from Stiglitz (1975) and Roumasset and Uy (1980) that in the agricultural sector, piece rate contracts are thought to avoid "effort shirking" but permit "quality shirking", Effort shirking may occur for instance in wage rates where increase in workers' effort is not rewarded by a proportional increase in income. The piece rate system is thought (with the share system) to avoid this kind of drawback. Conversely, piece rate contracts do not avoid quality shirking. Consequently, piece rate contracts may entail a subsequent drop in the output quality when output quantity is threatened to be slowed down or limited by quality requirements. Workers will be tempted to increase output quantity to the detriment of quality, especially when control by employers is not easy (Roumasset and Uy, 1980).

This may be the case in this fishery since during the three weeks of trip, the fishermen have to work without company control. Recall that the main task for the crew consists of sorting and storing the shrimp in commercial categories. It is then likely that this time-consuming task is considered as an impediment to the production rate by the crew members, especially when massive quantities of shrimp are taken on board. A more thorough workers' effort to sort the shrimp already on board would not be rewarded by any proportional increase in income. Conversely, it might even slow down the future fishing operations and therefore entail a decrease in the total quantity of shrimp to be caught. Therefore, in the present case, if crew contracts were only based on quantity, the possibility of quality shirking could not be disregarded. Here, the bonus component $(\varphi)$ provides incentives to the crew to maintain sorting quality and may counteract this risk of shirking occurrence. Indeed, in (3), the part of $\left(B_{1}\right)$ associated with the parameter $(\varphi)$ stimulates quality and grading requirements. This bonus thus rewards quality labour, thereby balancing, at least theoretically, the shirking tendency entailed by the piece rate contract.

The assertion of the efficiency of this "balance" remains however theoretical and very difficult to prove empirically. Indeed, it is not possible to estimate the gain for crew's revenue that a systematic quality shirking behaviour would entail. What is indisputable, conversely, is the companies' fear that the fishermen would shirk, as illustrated by the caution found on the crew members' pay slips: "Company will make tests on shrimp, for black shrimps, soft shrimps broken and bad grading. If quality and/or grading are not good this bonus [the grading bonus] will not be paid".

Lastly, regarding this shirking issue, one could argue that the effort and quality incentives provided by the present contract could have been directly achieved through a classical (and more simple) share wage. It remains indeed theoretically possible to bind the crew members to quality requirements of the output by remunerating them on the basis of the gross revenue (which is directly affected by the quality level) rather than on the output quantity. Stiglitz (1975) proposes one possible explanation for the piece rate contract continuation. He suggests that picce rates are used to "screen out" less productive workers when worker quality is variable and difficult to estimate by employers. He shows that it is theoretically possible to set piece rates sufficiently low so that only the most skilled workers will receive their opportunity wage and accept the job. This may be one of the explanations for the fact that, in the case of the crews, a mixed piece rate and bonus contract has been preferred to the usual share system.

\section{Role of the remuneration system in control of skippers' strategies}

In this second section, we propose a possible explanation for the form of the skippers' remuneration contract, and especially for the fact that it differs from the share contract. Our main hypothesis is that this particular remuneration scheme has been developed because it represents a "tool" to control and orient skippers' fishing effort towards shrimp whose sizes are in accordance with the commercial requests faced by the companies. To test this hypothesis, we propose to perform the following three-step test:

(A) The parameters $\left(\nu_{c}\right)$ that are modified deliberately by the companies can evolve independently from the market prices.

(B) The shift of the parameters $\left(\nu_{c}\right)$ that is observed over the end of the 1980 s is consistent with the inshore re-allocation of effort detected over the same period.

(C) The alternative explanations for this inshore fleet migration have to be rejected.

Step (A). Firstly the linear regressions that fit the discounted European market prices $\left(p_{c}\right)$ of the seven commercial categories were estimated for the three years 1987, 1989, and 1991 (Fig. 2) and the significances of these linear regressions were tested (Table 2 models $(i)$ ). The graphical observation of the Figure suggests that the prices have not changed over the period 1987-1991. This observation was confirmed by a statistical test. We tested whether or not there was a "category effect", this is to say, whether a significant difference occurs between the three slope parameters (remark: testing for an intercept change would have amounted to testing for a "year effect"). For this, the 1987 parameter was taken as reference and we checked whether or not the 1989 and 1991 slope parameters depart from it. The decision rules and results of the test are given in Table 3. The test failed to detect any difference in the three slope parameters. There is no category effect: the relative prices of the seven commercial categories have not 
Table 2. - Tests of significance of the estimated linear regressions of $(i)$ the European market prices $\left(p_{c}\right)$ or $(i i)$ the skippers ${ }^{\circ}$ remuneration parameters $\left(\nu_{6}\right)$, with the commercial categories $(c)$ for the three ycars 1987.1989 . and 1991 . In the present case $n=7$, Fo.(s), $=16.3$. The null hypothesis $I_{f}$ is the non-significance of the corrclation coefficient; $I_{0}$, rejucted if $F_{1 . n} \cdot 2>F_{t h}, I I_{0}$ accepted otherwise, with $F_{1 . n-2}=$ ESS $/($ RSSS $/(n-2))$ (sources $p_{r}:$ French Guyana Shrimp Producers Organisation). RSS: residual sum of squares, ESS: explained sum of squares.

\begin{tabular}{|c|c|c|c|c|c|c|}
\hline Year & $\begin{array}{l}\text { Estimated model: } \\
\text { (i) or (ii) }\end{array}$ & $\mathrm{R}^{2}$ & RSS & FSSS & $F_{1, n-2}$ & \\
\hline 1987 & (i) $p_{r}-10.91 r+117.07$ & 97.8 & 74.49 & 3333.2 & 223.7 & $P<0 .(x) \mathrm{I}$ \\
\hline 1989 & (i) $p_{r}=-11.13 r+121.97$ & 97.4 & 94.84 & 3668.5 & 193.3 & $P<0,0(0) 1$ \\
\hline 1991 & (i) $1 c_{r-}-10 . x f(r+120.76)$ & 97.6 & 80.30 & $33(04.9$ & 205.7 & $P<0,001$ \\
\hline 1987 & (ii) $p_{c}=-2.12 a+11.0 \mathrm{x}$ & 98.8 & 1.32 & 114.4 & 431.0 & $P<0.0(0)$ \\
\hline 1989 & (ii) $p=-1.8 x c+15.017$ & 96.4 & 3.66 & 99.5 & 135.7 & $P<0 .(x) 1$ \\
\hline 1991 & (ii) $)=-1.740+16,6 ; 1$ & 98.1 & 1.67 & 89.2 & 266.6 & $P<0.001$ \\
\hline
\end{tabular}

Table 3. - Test of comparison of slope parameters for the European market prices $\left(p_{c}\right)$. The slope parameters of the regressions estimated for 1989 and 1991 (noled rkg and reyl respectively) arc compal ed to the 1987 parameter taken as reference, i.e. $r r_{87}=6 x_{t h}$. The

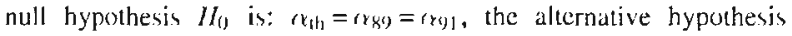

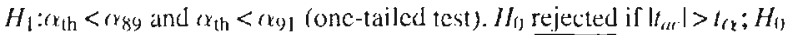

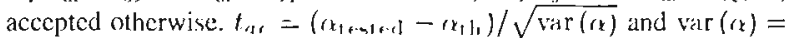
$S_{1}^{2}\left(1-R^{2}\right) /(n-2) S_{1}^{2}$. The value $t_{i q}$ is drawn from the Student's $t$ table (for $n-2$ d.f.). In the present case $\alpha_{x}-=\alpha_{1} h_{1}=-11.91, n=7$ and $t_{n}=2.016$.

\begin{tabular}{|c|c|c|c|c|c|c|}
\hline Year & $S_{1}^{2}$ & $S_{2}^{\prime 2}$ & $\left.r r_{t a s}+d\right]$ & ||$_{x \mid r} \mid$ & $I_{n}=2.016 \mathrm{j}$ & \\
\hline 1989 & 626.574 & 4.667 & $\alpha_{\star 83}=-11.439$ & 0.640 & $\left|I_{a C}\right|<l_{n}$ & N.S. \\
\hline 1991 & 564.202 & 4.667 & $\left(x x_{11}=-10\right) \times 61$ & 0.061 & $\left|t_{\mathrm{ar}}\right|<t_{\mathrm{rr}}$ & N.S. \\
\hline
\end{tabular}

N.S.: non significant difference with the reference value $x_{*}$, .

changed over the period 1987-91. On the other hand, although the parameters $\left(\nu_{c}\right)$ are doubtless determined as a function of market prices, they are controlled and set by the companies. The companies were therefore theoretically able to modify these parameters independently from the market prices. The significance of this artificially introduced category cffect on the remuneration parameters was tested, using the same procedure as the previous test. Firstly the linear regressions that fit the remuneration parameters $\left(\nu_{c}\right)$ of the seven commercial categories were estimated for the three years 1987, 1989, and 1991 (Fig. 3) and the significances of these linear regressions were tested (Table 2 models (ii)). In this case, the slope coefficient obtained for the 1991 regression appears to be statistically different (at $5 \%$ ) from that of the reference 1987 year (Table 4). This means that the parameters $\left(\nu_{c}\right)$ have been modified by the companies independently from the market prices $\left(p_{c}\right)$.

Step (B). Following the previous result, we have now to show that the change in the remuneration parameters is one possible explanation for the shift which has occurred in the fishing effort allocation over the period 1987-91. For this, the reasoning goes as follows. The 1989 and 1991 slope parameters decrease steadily in absolute value with respect to the 1987 reference value $\left(\left|\alpha_{89}\right|<\left|\alpha_{87}\right|\right.$ and $\left|\alpha_{91}\right|<\left|\alpha_{87}\right|$,
Table 4. - Test of comparison of slope parameters for the remuneration parametcrs $\left(\nu_{l}\right)$. The procedure and decision rules are similar to that of the previous test (Table 3). In the present ciase $r_{x \rightarrow}=r_{11}=-2.021 . n_{2}=7$ and $t_{\alpha}=2.1316$.

\begin{tabular}{|c|c|c|c|c|c|c|}
\hline Yeur & $S_{i j}^{2}$ & $S_{x}^{2}$ & $\left(x_{1}, a t+x\right)$ & $\left|t_{x r}\right|$ & $t_{1 .}=2.016$ & \\
\hline 1989 & 17.205 & 4.667 & $(8 \times 1)=-1.8855$ & 0.838 & $\left|I_{\text {II }}\right|<t_{\text {Ix }}$ & N.S. \\
\hline 1691 & 15.160 & 4.667 & $\left(x_{0}, 1\right)=-1.7 x_{5}$ & 2.155 & $\left|t_{\mathrm{ar}}\right|>t_{t .}$ & $*$ \\
\hline
\end{tabular}

N.S.: non significant difference with the reference value $\alpha_{x}$ i .

$*$ : denotes a $5 \%$ statistical difference with the reference value $\alpha_{8} 7$.

French market price $p_{c}\left(\mathrm{FF} \mathrm{kg}^{-1}\right)$

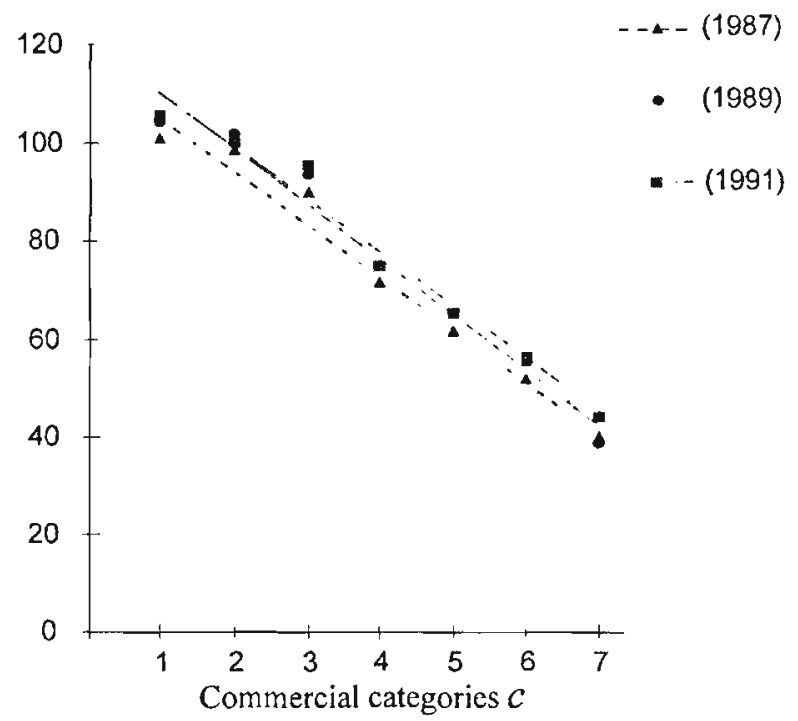

Figure 2. - Yearly discounted European market prices $\left(\nu_{c}\right)$ and estimated linear regressions for the three ycars 1987,1989 and 1991 (see Table 2 for the model parametcrs).

cf. Table 4). This means that the difference in the remuneration of the largest categories $(1,2$ and 3 ) and of the smallest ones $(5,6$, and 7) progressively declines over the period 1987-91. In other words, it became less profitable for the skippers to concentrate their effort towards large, scarce adult shrimp than it used to be before 1987. By gradually modifying the 


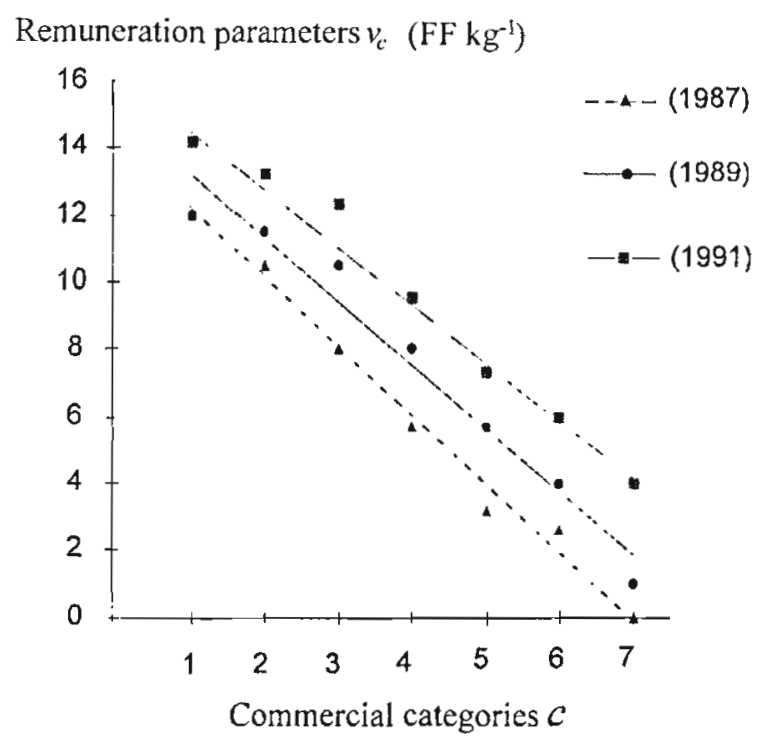

Figure 3. - Remuneration parameters $\left(p_{c}\right)$ and estimated lincar regressions for the three years 1987, 1989 and 1991 (see Table 2 for the model parametcrs).

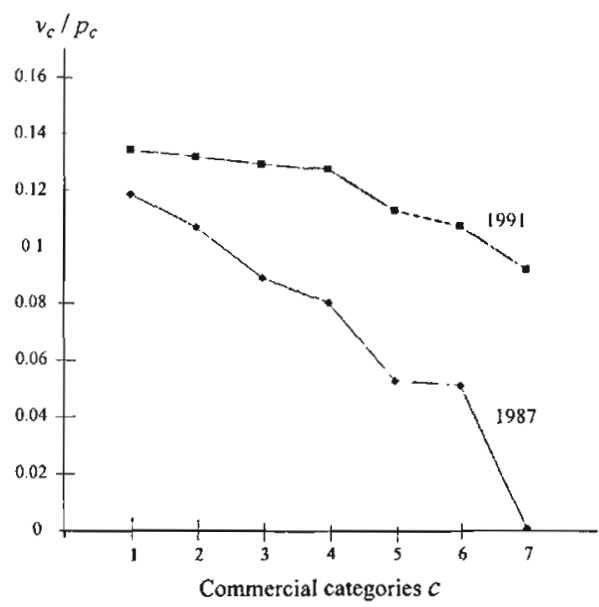

Figure 4. - Evolution of the ratios $\left(\nu_{c} / p_{c}\right)$ between 1987 and 1991. Regarding the fact that the relative market prices of the different categories have not changed (Table 3), the Figure illustrates the effects of the modifications in the remuneration parameters. While the 1987 ratio actively discouraged skippers from seeking out small shrimp, the changes in the remuneration parameters largely reduced this discouragement in the following years.

parameters $\left(\nu_{c}\right)$ the companies lessened the incentives for the captains to look for large shrimp. The direct comparison of the ratios of price and remuneration parameters between the two years 1987 and 1991 makes it clear (Fig. 4).

The spatial distribution of fleet effort is then examined. Its evolution may be visualised through the curve of the fleet's sounding (Fig. 5). This sounding curve indicates the average depth of the fishing zones where the fleet operated. The curve shows that from 1982 to 1987 the fleet concentrated the main part of its effort in depths around 46 meters. The curve then starts to decline from 1988 onwards. This indicates that the fleet slowly re-oriented its effort towards shallower-water zones. Simultaneously, the percentage in catches of the small commercial categories shows an increasing trend from 1988 onwards (Fig. 6). Recalling the depth-dependence of the resource distribution, this trend in catch composition appears to be consistent with the inshore re-allocation of effort. By operating in zones closer to the coast, the flect switched from large mature adults to younger, smaller shrimp. Both the consistency and the synchrony occurring among the three phenomena (the change in remuneration parameters, the re-orientation of fleet effort, and the increase in small shrimp proportions) give way to a cause-effect relationship.

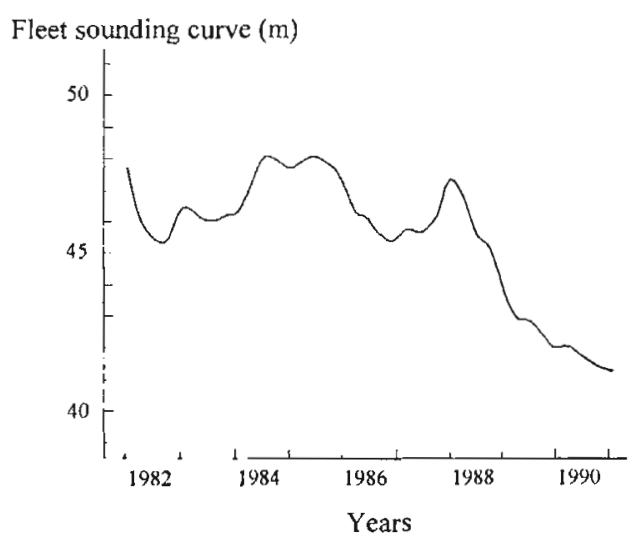

Figure 5. - Trend of the fleet sounding curve (obtained by a centered moving average procedure on raw data) over the period 1982-90. From 1982 to 1987, this trend fluctuates around 46 meters then starts to decline after 1987 to 41 meters in 1990 (source: Béné, 1996).

Nevertheless, one may wonder what incentive(s) might have led the companies to impose a reorientation of effort towards less profitable small shrimp. As explained in the fishery's history, the French Guyana companies had to face an export reorientation during the last decade (Fig. 1). From 1988 onwards, they were required by the French processors to supply smaller shrimp than they used to for the Japanese and US processors before 1987. However, as shown in step (A), the relative European market prices have not changed at all over this period. In these circumstances, if the remuneration system had been a classical share system, the captains (who choose areas where they expect to get catch size compositions which maximise their trip revenues) would not have had an incentive to redistribute their efforts toward smaller (and less remunerated) shrimp (since under share contract the remuneration is based on market prices). Consequently, they would probably not have changed their effort allocation, and the companies would not have been able to satisfy the French processors' new requirements. Under the present remuneration system, on the other hand, the companies had the possibility to 


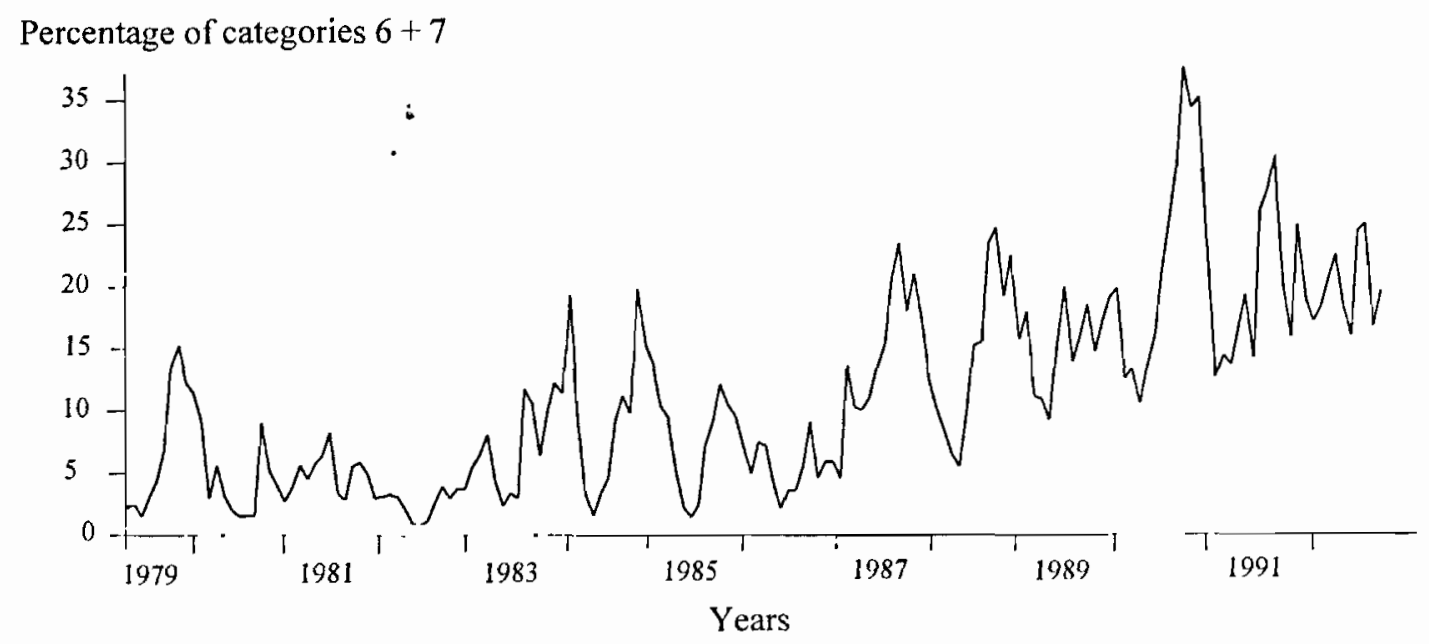

Figure 6. - Cumulated percentage of the two smallest commercial categories $(6+7)$ in the total catches over the period 1979-92. The rising trend observed in the data after 1988 is consistent and synchronous with the fleet movement toward shallow waters viewed in Figure 5.

modify the remuneration parameters as wished. This is indeed what they did in such a way that the skippers were induced, in their turn, to re-orient their effort towards smaller shrimp.

Step (C). If the existence of a cause-effect relationship between the shift in remuneration parameters and the effort allocation is now possible, we still have to identify and then reject the other possible alternative(s) for the inshore effort movement. What reason, other than a response to remuneration incentives, may induce fishermen to change their effort allocation? The possible alternative for this fleet movement is a response 10 changes in shrimp distribution and/or availability. It seems indeed possible that the disappearance of largesized shrimp due to environmental changes and/or overexploitation of the mature shrimp may deplete deep-water abundance to a point where it is no longer profitable to fish offshore. Furthermore, a simple inshore migration of the entire stock (without implying any stock depletion) may also suffice to stimulate a subsequent fleet inshore movement. In both cases, however, the spatial distribution of the resource would have reflected the stock distribution change (inshore migration or offshore depletion). Consequently, testing the hypothesis of a resource availability/abundance modification amounts to determining if the spatial distribution of the stock has evolved during the period in concern. In a previous study, Béné (1996) addresses this hypothesis and tests whether or not the spatial distribution of the stock has changed over the period 1984-90. The test failed to detect any change in the resource distribution. This means that the stock abundance has not experienced any change in its spatial structure over the period studied. The fleet movement was therefore not induced by a change in the distribution of the resource.
Finally, beyond the simple analysis of the remuneration contract adopted in one given fishery, this study carries some "wider" policy message. This analysis indeed does not merely illustrate for the specific case of the fisheries the tight linkage which exists between the structure of the labour contracts and the worker behaviours. It also illustrates how the commercial constraints initially faced by the companies were then "forwarded" to the fishermen through the remuneration system and finally turned out to modify the spatial distribution of the fishing effort. In other words, it shows to what extent changes in the consumer preferences and/or the market dynamics ultimately alter the exploitation pattern of a marine resource. In this sense, it recalls that fisheries are complex renewable resource exploitation systems located at the interface between markets and resource dynamics (Béné, 1997) and it thus reasserts the importance of incorporating social sciences and economic considerations when planning aquatic resource policies.

\section{CONCLUSION}

The objective of this study was to analyse the remuneration system of the French Guyana shrimp fishery. This study relied less on the three academic approaches developed in contract theory (Agency theory, Transaction Cost Theory, or Incentives Theory) and more on an empirical knowledge of the fishery as well as an analysis of the actual contracts used by looking at the fishermen' pay slips. Although this work initially refers to predictions proposed in reference literature of contract theory, it does not try to adjust systematically the empirical observations to the corresponding theoretical framework. The resulting analysis avoids the simplification inherent in theories 
and stays very close to the exact form of the contracts. The conclusion of the analysis is that this remuncration system, the form of which differs from the traditional share system, was adopted by the companies because it offers the possibility to control and monitor the crews' work on board and the skippers' fishing strategies.

In particular, the algebraic analysis of the contracts shows that the crew's remuneration is a piece rate wage mixed with bonuses based on quality requirements. In classical literature, the piece rate contract is assumed to avoid effort shirking. However, it is also thought to lead to quality shirking. The introduction of quality bonuses can be regarded as the employers' attempt to reduce this possible quality shirking behaviour. By adopting this combined contract, the companies seem able to stimulate and maintain both effort input and quality labour amongst the crew members. However, the efficiency of this 'balance' is difficult to estimate accurately.

It is then shown that the skippers' remuneration system also differs from the share contract. Here, the parameters from which the trip remuneration is calculated are not the market prices, as under share contract, but independent parameters controlled by the companies. This particular procedure allows the companies to uncouple the remuneration of their skippers from the exclusive influence of the market prices. In particular, in the present case, it was shown that the remuneration parameters, although being broadly determined as a function of prices, had been modified by companies while the corresponding market prices did not change. This shift permitted the companies to drive the skippers to re-orient their fishing efforts towards small shrimp, in order to respond to changes in market and processors' requirements. If the remuneration system had been a classical share system, the unchanged market prices would not have provided such size change incentives. The observation of the spatial distribution of the fishing effort during the period concerned is consistent with this hypothesis: the fleet has moved gradually towards areas where smaller shrimp are known to be caught. The analysis of the size composition of the commercial catches also confirms this modification. Furthermore, in a complementary study, Béné (1996) addresses the main alternative for this fleet movement, that is, whether this inshore effort re-allocation may be a fishermen's response to resource availability/abundance modifications. The analysis indicates that there was no significant change in the resource spatial distribution over that period. Consequently, this alternative has to be rejected and the hypothesis that the remuneration scheme offers an efficient mechanism to control the skippers' fishing strategies is tenable.

\section{Acknowledgments}

I am grateful to Prs. Ray Hilborn and James R. Wilson for their helpful comments on this manuscript and to Dr. P. Moguedet for the many discussions we had about the fishery. This research was supported by grants from IFREMER and the CNRS (GDR 1107: Dynamic models and control of renewable resources).

\section{REFERENCES}

Anderson E. E. 1994. Crop sharing in the fishery and industry equilibrium: comment. Mar. Resour. Econ. 9, 67-72.

Anderson L. G. 1982. The share system in open-access and optimally regulated fisheries. Land Econ. 58, 435-449.

Bell C. 1977. Alternative theories of share-cropping: some tests using evidence from northeast India. J. Dev. Stud. 13, 317-346.

Béné C. 1996. Effects of market constraints, the remuneration system, and resource dynamics on the spatial distribution of fishing effort. Can. J. Fish. Aquat. Sci. 53, 563-571.

Béné C. 1997. Dynamique et adaptation d'un système-pêche face aux perturbations de son environnement: analyses et modélisations dynamiques du couplage écologie-économie. Thèse dr. Univ. Pierre et Marie Curie (Paris VI), Paris, 237 p.
Béné C., P. Moguedet 1994. Technical consultation on sustainable fisheries development in the WECAFC area, a theoretical contribution: the French Guyana shrimp fishery. Caraballeda, Venezuela, 18-22 Oct. 1993, FAO Fish. Rep. R 503.

Braverman A., J. E. Stiglitz 1982. Sharecropping and the interlinking of agrarian markets. Am. Econ. Rev. 72, 695-715.

Cheung S. N. 1969. The theory of share tenancy. Press Univ. Chicago, Chicago.

Dintheer C., B. Gilly, J-Y. Le Gall, M. Lemoine, J. Rosé 1991. La recherche et la gestion de la pêcherie de crevettes Pénéides en Guyane française de 1958 à 1988: trentes années de surf. In: La recherche face à la pêche artisanale. J.-R. Durand, J. Lemoalle, J. Weber eds. Symp. Int. ORSTOM-IFREMER, Montpellier, 3-7 July 1989, 859-870.

Garcia S. M. Lemoine, E. Le Brun 1985. Seasonal and long term variability of recruitment in French Guyana shrimp 
fishery of Penaeus subtilis. FAO Fish. Rep. 327. Suppl, 242-250.

Gilly B., Y. Cochet 1988. Analyse économique de la pêcherie crevettière de Guyane françaisc. Rapp. interne IFREMER, DRV-88.023-SDA, Paris. 47 p.

Haemaelaeinen R.P., J. Ruusunen, V. Kaitala 1990. Cartels and dynamics contracts in sharefishing. J. Env. Econ. Manag. 19, 175-192.

Hottlet O. 1992. The European Market for frozen shrimp. Infofish Int. 92, 16-20.

Josupeit H. 1992. Single market in the EEC, good or bad news for traders? In: Proc. $3^{\text {rd }}$ Global Conf. shrimp industry. H. de Saram, T. Singh eds. Hong Kong, 14-12 Sept., GlobeFish, 54-72.

Le Cabellec J. 1984. Analysc ćconomique de la pêche crevettière en Guyane françaisc. IEDOM, Doc. interne, Cayenne, $63 \mathrm{p}$.

Lhomme F. 1992. Le recrutement des postlarves de la crevette Pencieus subtilis dans deux estuaires de Guyane française. Ann. Inst. Océanogr. 63, 169-178.

Maran M. 1974. The decline of American whaling, Ph.D. Diss. University of Pennsylvania.

Moguedet P., D. Nérini, 1:. Gueguen 1994. Evaluation du volume et cartographie des captures accessoires de la pêcherie de crevettes Pénéides en Guyane française. Contrat d'étude C.E.E.-DG XIV.92-3504. Rapport final, $100 \mathrm{p}$.

Newbery D. M. G. 1977. Risk-sharing, sharecropping and uncertain labour-market. Rev. Econ. Stud. 4A, 584-594.
Plourde C., J. B. Smith 1989. Crop sharing in fishery and industry equilibrium. Mar. Resour. Econ. 6, 179-193.

Reid J. 1976. Sharecropping and agricultural uncertainty. Econ. Dev. Cult. Change 24, 549-576.

Roumasset J., M. Uy 1980 . Piece rates, time rates and teams ; explaining patterns in the employment relation. J. Econ. Behav. Org. 1, 343-360.

Sass M. E., K. J. Roberts 1979. Characteristics of the Louisiana Shrimp fleet, 1978. Sea Grant Publication $\mathrm{N}^{\circ}$ LSU-TL79-006, Louisiana State University.

Stiglitz J. E. 1974. Incentive and risk sharing in sharecropping. Rev. Econ. Stud. 41, 219-256.

Stiglitz J. E. 1975. Incentives, risk and information: Notes toward a theory of hicrarchy. Bell J. Econ. 7, 552-579.

Sutinen J. G. 1979. Fishermen remuneration systems and implications for fisheries development. Scott. J. Pol. Econ. 25, $147-162$.

Venail]e L. 1979. La pêcheric de crevettes Pénéides du plateau guyano-brésilien. Sci. Pêche, Bull. Inst. Pêches Marit. 297, 1-15.

Villegas L., A. Dragovitch 1984. The Guianas-Brazil shrimp fishery, its problems and management aspects. In : Penaeid Shrimps: their biology and management. J. A. Gulland, B. J. Rothschild eds. Fishing News Books, 60-70.

Zoeteweij H. 1956. Fishermen's remuneration. In: The economics of fisheries. R. Turvey, J. Wiseman eds. FAO, Rome, 18-41. 